\title{
Türkiye'de Sağ-Muhafazakâr Siyasetçilerin Devleti Algılama Yordamları Üzerine Bir Değerlendirme
}

\author{
An Evaluation of State Perception Procedures of the Right Wing \\ Conservative Politicians in Turkey
}

\section{Dr. Yaşar Suveren}

\section{Öz}

Devletin nasıl tanımlandiğı ve algılandiğ su karşısinda nasıl konum alındiğı siyasal düşünce ve ideolojilerin ayırt edilmesi ve anlaşılması bakımından önem taşımaktadır. Türkiye'de sağ siyaset geleneğinin devlete atfettiği önem ve değer söz konusu olduğunda bu geleneğin devlet tahayyülünü soruşturmak başl başına ilgiye değer görünmektedir. Bir entite olarak devlet, sağ-muhafazakâr siyasetçilerin büyük çoğunluğu için oldukça önem ve değer verilen bir güç ve otorite kaynağı olarak görülmektedir. Meşru güç ve otoriteyi temsil eden devlet, oldukça çeşitlenen bir dizi mitolojik ad ve sifat etrafinda tanimlanmakta ve algilanmaktadir. Devlet tanimlanırken en sik müracaat edilen sifatmecaz onun "baba" oluşudur; yaygin kullanılan tipik tamlama ise "devlet baba"dır. Bu mecaza eşlik eden ayrılmaz bir başka önemli unsur ise "kutsallk" veya "kutsiyet"tir. Böylesi bir algi ve bununla ilintili devletotorite tasavvurunun sağ-muhafazakâr siyasetçiler nezdinde karşıllk bulmasının, modern siyasetin siyasetçilerin önüne koyduğu güncel meselelerin tartışılması ve çözüm olasılıkları önünde ciddiye alınması gereken bir engel oluşturduğu görülmektedir. Mevcut makalenin üretilmesine zemin oluşturan çalışma Devlet Planlama Teşkilatinın Düzey II. kriterlerine göre Türkiye’yi temsil niteliğini haiz 13 il merkezinde 6 siyasi partiye (Adalet ve Kalkınma Partisi, Milliyetçi Hareket Partisi, Saadet Partisi, Demokrat Parti, Anavatan Partisi ve Büyük Birlik Partisi) mensup toplam 126 siyasetçi ile yarı-yapılandırılmış bir soru formu eşliğinde, yüz yüze görüşmeler yoluyla gerçekleştirilmiştir.

Anahtar Kelimeler: Siyaset Sosyolojisi, Muhafazakârllk, Sağ Siyaset, Devlet, Otorite

\begin{abstract}
How the state is described and perceived, and how the people position themselves with respect to the state is crucial to distinguish the political decisions and ideologies. When the importance and value attributed to the state by the right-wing politics is considered, it is especially important to examine the state imagination of this tradition. The state, as an asset area, is perceived by the vast majority of the right-conservative politicians as an essential and valuable source of power and authority. The state, which represents the legitimate power and authority, is defined and perceived through a wide variety of qualities, names and adjectives. When the state is described the most common adjective-metaphor is the "father" and another common description is "state father". This is the most common paternalist metaphor that was used almost by the all politicians while promoting or criticizing the state. It might be mentioned that such a pre-modern understanding of history and the related state vision that has a response in the rightist-conservatist politicians is an important obstacle over the debates and solutions about the actual questions that modern politicians have to discuss. The field work of this article has been completed in 13 different cities of Turkey; with 126 politicians belong to 6 right wing-conservative parties with the semi-structured questionnaires and face-to-face interviews.
\end{abstract}

Keywords: Political Sociology, Conservatism, RightWing Politics, State, Authority

Dr. Yaşar Suveren, Sakarya Üniversitesi Fen Edebiyat Fakültesi, ysuveren@gmail.com 


\section{Giriş}

Devletin nasıl tanımlandığı 1 ve algılandığının, devlet olgusu karşısında nasıl konum alındığının siyasal düşünce ve ideolojilerin anlaşılması ve ayırt edilmesi bakımından önem taşıdığ söylenebilir. Türkiye'de sağmuhafazakâr siyaseti anlamak bakımından bu siyasi geleneğe mensup siyasetçilerin devlet-otorite ve devlet ile toplum arasındaki ilişkilere nasıl baktığının ortaya konulmasının Türkiye'deki siyasal yapı ve kültürü anlamlandırabilmek için kayda değer bir soruşturma alanı teşkil ettiği söylenebilir. Özellikle, Türkiye’de sağ siyaset ve düşünce geleneğinin devlete atfettiği önem, öncelik ve değer söz konusu olduğunda bu geleneğin devlet tahayyülünü soruşturmanın ise başlıbaşına ilgiye değer bir konu olduğu söylenmelidir. Öztan’n da belirttiği üzere: “Türkiye'de 'devlet' kavramının ayr1calıklı konumunu tahkim eden konvansiyonel politik gelenek ve bu geleneği uygulanabilir kılan bir siyasal kültür çerçevesi mevcuttur [...] Türkiye özelinde ülkenin siyasal yapılanması ve kültürü mercek altına alındığında 'devletin kutsiyeti' inancının ve 'devlet baba' tamlamasıyla özetlenen paternalist zihniyetin hatırı sayılır bir ağırlığa sahip olduğu sıkça dile getirilen bir olgudur" (Öztan, 2012, s.426).

$\mathrm{Bu}$ makalenin üretilmesine vesile olan doktora tez çalışmas $1^{1}{ }^{2}$ tasarlanırken yalın bir entite olarak doğrudan 'devlet' algısını soruşturmak hedeflenmemişti. Öncelikli amaç tarihsel ve güncel siyasal bir bağlam içinde devlet-toplum ilişkilerinin nasıl algılandığı ve esas olarak da bu ilişkiselliğin cumhuriyet-modernleşme süreci içinde, sağ-muhafazakâr siyasetçilerce nasıl değerlendirildiği soruşturulmak istenmişti. Temel amaç bu olmasına karşın alan çalışmasında, kendileriyle görüşülen siyasetçilere bir 'açılış sorusu' olarak yöneltilen, "devlet denildiğine aklınıza neler geliyor? Devleti nasil tarif edersiniz?" sorusuna verilen yanıtlar, başlı başına "devlet" ve giderek "otorite" konusunun sorunsallaştırılmasını gerekli kılmıştır. Ayrıntılarına ileride değinileceği üzere, siyasetçilere yöneltilen 'açlış sorusu'na verilen yanitlar 'devlet' hakkında güçlü bir mitolojik söylem ve algının var-

1 Suveren, Y. (2013). The Right Wing Conservative Politicians in Turkey: Ideological and Political Imaginations. (Yayımlanmaa mış Doktora Tezi). ODTÜ Sosyal Bilimler Enstitüsü, Ankara.

2 Yazarın doktora tez çalışması, Doçent Doktor Mustafa Şen>in proje yürütücüsü olduğu ve TUBİTAK»ın destek verdiği Türkiye'de Muhafazakâr Siyasetçi Profili (2010, Ankara; Proje No: 107K299), başlığını taşıyan bir araştırma projesinin niteliksel verilerine dayalı olarak üretilmiştir. Yazar, sözü edilen proje süresince bursiyer olarak TUBİTAK tarafından desteklenmiştir; bu vesileyle yazar kuruma teşekkür borçludur. lığına işaret etmekteydi. 'Devlet'e ilişkin sağ siyaset geleneğinin gerek siyasal sosyalizasyonla edinilen gerekse de bu siyasi kültüre içkin tarih yazımı ve diğer pedagojik vasıtalarla içselleştirilerek yeniden üretildiği söylenebilecek, mitik bir algı ve imgeleme sahip olduğu söylenebilir.

Fakat öte yandan bu algının modern zamanlarda siyasal ve sosyolojik bakımdan bir önem taşıyıp taşımadığı başlangıçta bizim için birtakım muğlaklıklar taşımaktaydı. Ancak bu muğlaklığa karşın sözü edilen algının güncel siyasal durum ve koşullarla olan rabita ve bağlantısı belirginleştiği ölçüde, ortaya çıkan durumun önemli bir sosyolojik soruşturma alanı teşkil ettiği görülmüştür. Yukarıda belirtilen amaç doğrultusunda devletin nasıl tarif edildiği ve kavramın/olgunun zihinsel-bilişsel tezahürlerinin söyleme nasıl yansıdığı, (yapılıyorsa eğer) devletin sorunsallaştırılma yordamlarının neler olduğu bu makale çerçevesinde anlaşılmaya çalışılmıştır.

\section{Veri ve Olguların Sunumu ${ }^{3}$}

Bir varlık alanı (entite) olarak devlet, görüşülen sağmuhafazakâr siyasetçilerin büyük çoğunluğu için oldukça önem ve değer verilen bir güç ve otorite kaynağ 1 olarak görülmektedir. Meşru güç ve otoriteyi temsil eden devlet, çok çeşitli nitelik, ad ve sıfatlar etrafında tanımlanmakta ve algılanmaktadır. Devlet tanımlanırken en sik müracaat edilen sıfat-mecaz onun "baba" oluşudur; yaygın kullanılan tipik tamlama ise "devlet baba"dır. Hemen her siyasetçi tarafından yüceltilirken de yerilirken de kullanılan en yaygin kullanılan paternalist sıfat-mecaz budur. Bu mecaza eşlik eden ayrılmaz bir başka önemli nitelik ise devletin "kutsallı̆̆ı" veya "kutsiyeti"dir.

Devlet, beşeri dünyada en meşru güç ve otorite kaynağıdır. Varlığı 'kutsal' olduğundan kararları ve tasarrufları sorgulanmamalıdır. Evde babanın kararları ve

3 Mevcut makalenin üretilmesine zemin oluşturan alan çalışması Devlet Planlama Teşkilatı̉nın Düzey II. kriterlerine göre Türkiye’yi temsil niteliğini haiz 13 il merkezinde 6 sağmuhafazakâr siyasi partiye (Adalet ve Kalkınma Partisi, Milliyetçi Hareket Partisi, Saadet Partisi, Demokrat Parti, Anavatan Partisi ve Büyük Birlik Partisi) mensup toplam 126 siyasetçi ile yarı-yapılandırılmış bir soru formu eşliğinde, yüz yüze görüşmeler yoluyla çalışmanın yazarı tarafından gerçekleştirilmiştir. Makale içinde mülakatlardan alıntı yapılan siyasetçilerin kişisel verilerine araştırma etiği kuralları gözetilerek yer verilmemiş sadece mensup oldukları siyasi partilerin adları anılmıştır. 
otoritesi nasıl herkes tarafından kabulleniliyorsa, eve benzetilen ülkenin güç ve otoritesini de ülkenin "babası" olan devlet temsil eder. O, "tıpkı bir baba gibi" ülkenin huzur, mutluluk ve güven kaynağıdır. Herkese eşit ve adil davranan devlete, herkes de destek ve taraftar olmalıdır. Devletin varlık sebebi milletse, milletin varlık sebebi de devlettir; bu ikisinden birinin eksikliği diğerinin varoluşunu olanaksız kılar. Devlet toplumun ta kendisi hatta onun "teşkilatlanmış halidir". Devlet olmazsa Türk milleti ne varlığını ne de yaşamını sürdürebilir. Devlet her zaman ve koşulda güçlü olmalıdır. Devlet gücünü toplumun "birliği ve bütünlüğünden" alır. "Devletler mücadelesi aslında milletler mücadelesi" olduğundan devlete başkaldırmak milletin varlığına da "ihanettir". Türk milletinin en karakteristik vasfi, onun "devlet kurma yeteneğì"dir. "Türkün beş-altı bin yıllık geçmişi” bu yeteneği cisimleştiren sayısız örnekler içermektedir. $\mathrm{Bu}$ vasıf ve yetenek "ebed müddet devlet" deyişinde anlam kazanır. "Milletin varlık sebebi" olarak görülen devlet her zaman bireylerin üstündedir. "Devletin varlığı, birliği ve bekası" söz konusu olduğunda devlet, her şeyden önce gelir.

Devlete yönelik bu tarif ve algılar gerçekleştirilen mülakatlarda dile getirilen ifadelere dayalı olarak derlenmiştir. Bu özette yer alan ifade ve yargılar Adalet ve Kalkınma Partisi (AKP), Milliyetçi Hareket Partisi (MHP), Demokrat Parti (DP) ve Büyük Birlik Parti'li (BBP) siyasetçilerin büyük ölçüde ortaklaşan tarif ve algılarını ve kısmen de Saadet Parti'li (SP) siyasetçilerin görüşlerini yansıtmaktadır. Güçlü bir eğilimi temsil ediyor olmasa da, bu özetteki ifade ve görüşlerle ihtilaflı olan, bu ifadelere mesafeli tarif ve algilara da değinmek gerekiyor. Örneğin, devletin varlığı, gücü, otoritesi ve kutsallığ kabul edilmekle birlikte, ona atfedilen bu niteliklerinin eleştirildiği ve sorgulandığını da belirtmek gerekiyor. Devletin, otorite ve gücünün sinırlarının belirlenmesi gerektiğini, karar ve uygulamalarında adaleti ve eşitliği gözetmesini, ideoloji ve irade dayatmasını yanlış bulduğunu belirten anlatı ve eğilimler de söz konusudur. Fakat yinelemek pahasına bunun görüşülen siyasetçiler arasında güçlü bir eğilim olmadığı belirtmelidir.

\section{Otorite ve Gücün Kaynağı Olarak “Kutsal Devlet Baba" veya Devlet Mitosu}

Yukarıda da belirtildiği üzere, sağ-muhafazakâr siyasetçilerin çoğu, devleti tarif ederken ya tek başına "baba" ya da "devlet baba" mecazına başvurdular. Bu mecaza göre evin "reisi” olan babanın güç ve otoritesi mutlaktır ve kararları sorguya açı değildir. Paternalist değerlerin hüküm sürdüğü evde aileyi temsil eden baba, evin tabii "reisidir" ve onun yegâne temsilcisidir. Ailenin kutsallığı devlete de yansitılmakta ve ona sıklıkla kutsiyet atfedilmektedir. AKP'li bir siyasetçinin değerlendirmesine göre: "gelenekten ve tarihten gelen bir anlayışla bu ülke insanlarının devlete bakışı diğer milletlerden çok farklıdır". "Bizim insanımız" devleti "baba" gibi görmektedir; "bir ailedeki baba neyse, devlet de odur, yani bir otoritedir. Dolayisıyla devlete karşı saygısızlık iyi değildir". Toplumun olduğu gibi kendisinin de devleti "baba" olarak gördüğünü belirten bir diğer AKP'li siyasetçiye göreyse Selçukluları da, Osmanlıyı da, cumhuriyeti de kuran güç, "devlet baba otoritesi"dir:

Nasıl bir evde baba her şeyi yapar, her şeyi söyler, gerekirse döver, gerekirse kızar ya! Kabul edelim veya etmeyelim bizdeki anlayış genellikle böyledir. Bu konuda rahmetli babam, 'devlet ateş gibidir, çok uzaklaşırsan donarsın, çok yaklaşırsan yanarsın' derdi. Bir de, devletin belli kuralları var, belli prensipleri var, prosedürleri var işlemesi için, var olabilmesi için. Onlara dokunmayacaksın, ellemeyeceksin. Neden? Bireylerin devlete gücü yetmez, bireysel olarak mücadele edenin devlete gücü yetmez, ama her zaman bireyin devletine de sahip çıkman lazım bana göre.

AKP’li bir diğer siyasetçi için ise "yasak koyabilen ama özgürlüğü de verebilen bir "organizasyon" olan devlet, "kutsaldır". Devlet içinde yaşayan "aile bireyleri gibi" olduğumuz için: "devlet neyi emrederse biz onu uygulamak zorundayı, devlet neyi yasaklamışsa biz de o yasaklara uymak zorunluluğundayız; Osmanlida da "Türk Töresi"nde de devlet olmazsa olmazdır zaten." Devletin "kutsi" olduğunu belirten bir diğer AKP'li siyasetçiye göre de "herkesin devlete taraf olması" gerekmektedir; vatandaşı "yönlendiren, kalkındıran ve ona hizmet sunan devlet" aynı zamanda onun "güvenliğini ve namusunu teminat altına alan kutsal bir teşkilattır". "Devlet baba" algısını yineleyen MHP’li bir siyasetçi için ise devlet:

[...] belki bağırabiliriz, kızabiliriz, dedim ya biz bayrağımızı, devletimizi babamızı sever gibi seviyoruz. Yani dövse de, aç da bıraksa, ne yaparsa yapsın, biz babamızı severiz. Ona da devlet baba deme nedenimiz budur zaten. [...] Hayır, bizde devlete isyan olmaz. Dediğim gibi babaya kızılmaz, dövse de, o babandır senin [...] Bu bir inanç meselesi, inanç, inanç. Yani inanıyorsun ki bu devlet senin, daima hoş görmek zorundasın onu. Ataya saygiya mecbursun.

Tarih sahnesinde "en çok devlet kuran" milletlerden birisinin Türkler olduğunu söyleyen MHP’li bir siyasetçiye göre: 
[...] devlet bizim için çok önemli. Devlet bana göre baba olmalı. Baba da bütün evlatlarına eşit davranmalı, birine üvey birine öz olarak davranmamalı. Devlet elle tutulur, gözle görülür bir şey değil, onun için bu anlayış daha doğrusu devlet kademesinde görev yapan insanlar, önce devletin ne olduğunu o görev yapan insanlar bilecek, onu bildiği için de topluma hizmet ederken üvey, öz falan ayırmadan hizmetlerini böyle yapacaktır. Benim devletten anlayışım, kastım budur. Gerektiği zaman da tabii kızar, ama gönlünü de alır. Benim devlet anlayışım böyle, devletin bir baba olduğuna inanıorum.

Devletin baba figürü üzerinden tanımlandığı ve ona kutsiyet atfeden bu algilamalar onun "bekasının" ve "gücünün" de devamını zorunlu kılmaktadır. Devlet her koşul ve zamanda var olmalıdır ki millet de varlığını devam ettirebilmeli. Anlatılarda dile getirilen bu anlayışa göre devlet ve millet birbirini aynı anda var eden bir ikilik veya oluştur; devlet ve millet (veya toplum) kendi başlarına var olamayan birer entitedirler. Bu iki entite birbirini aynı anda mümkün kıldığı (veya yeniden ürettiği) içindir ki her ikisi de güçlü olmak durumundadır. Hem "kritik bir coğrafyada yaşadığımız için hem de milli birlik ve beraberliği sağlamak için devletin ve milletin hep güçlü kalması gerektiğini” düşünen bir AKP'li siyasetçi şunları dile getiriyor:

[...] Biz hakikaten öyle bir bölgede yaşıyoruz ki devlet olarak, hem Ortadoğu'ya yakın, hem Balkanlar var, bir taraftan Rusya’nın komşuyuz. Bu nedenle devletimizin çok güçlü olması lazım. Aynı şekilde ordumuzun da güçlü olması lazım. Biz böyle bir yapıdan geliyoruz, tarihimiz boyunca devletine sadık kalmış, devletiyle övünmüş, her türlü fedakârlığı göstermiş bir milletiz. Devlet söz konusu olduğunda, birey olarak üzerimize düşen neyse, bunlara uymamız gerek. Bunlara uyarsak, devletimizin daha güçlü yerlere geleceğinden ben eminim. Devlet ve millet olarak karşılıklı sorumluluklarımız vardır; biri olmadan diğeri ayakta kalamaz.

Ülkücülerin devlete bakışında "devlet baba” anlayışının "daim” olduğunu ama bunun ötesinde devlete "derin bir hissi bağlılığın" da olduğunu hatta bunun "platonik bir aşk" gibi görülebileceğini belirten MHP’li bir siyasetçiye göreyse devlet, zaman zaman karar ve uygulamalarıyla yanlışlıklar yapsa ve bunlar ülkücülere "acı verse" de:

[...] Bizim için devlet her şeye rağmen kutsaldır. Tamam, nihayetinde onu bir baba olarak da görürüz. Size hissi gelebilir ama devlete bağlılı̆̆ımız bir aşk gibidir. Bunu size ironik bir şekilde anlatayım, bizim devlete olan aşkımız platonik bir aşktır. Devlet bizim çok sevdiğimiz ama bize asla gereken sevgiyi vermeyen, aşkını esirgeyen genç bir kız gibidir. Anlatabildim mi? Biz ona şiirler, mektuplar yazarız. Devlet bunları okur, gülümser... bakmaz yani. Ama koluna başka bir erkeği takar gider... Bu nasıl bir şey? İsyan edersiniz, kızarsınız, belki içinizden küfür de edersiniz ama o sıra bir ezan okunur ve ezanın okunmasının burada bir devlet olması anlamına geldiği düşünürsünüz. O devlet olmasa, beğenmediğiniz, eleștirdiğiniz, kızdığınız, küfrettiğiniz devlet olmasa başınıza neler gelebileceğini düşünürsünüz. Ve bu ülkeden başka yerde yaşama şansınız olmadığını, başka bir yerde mutlu olamayacağınızı düşündüğünüz zaman da yeniden devleti sevmeye başlarsınız. Bu böyle bir şey, bu çok zor bir şeydir. Ama yine de severiz [devleti]. Yani devletin önemli olduğunu biliriz. Devlet bizim için önemlidir [...] Bunlar bizim aslında bu devlete olan sevgimizin ipuçlarıdır yani. Şu an için bizim camiamız içerisinde en beğenmediğimiz nokta devleti çok eleştirmek zorunda kalmamız. Gerçekten bu camiamızı da, beni de üzüyor.

Devletin ve milletin bekası için bu unsurların her zaman güçlü olması gerektiğini ifade eden MHP’li bir başka siyasetçiye göre her milletin ve devletin "var olma hakkı" vardır ve bunu "savunmak engellenemez". Kendi siyasi anlayışının bunu "devlet-ebetmüddet" biçiminde "sloganlaştırdığını" söyleyen bu siyasetçiye göre:

[...] millet olarak siyaseten, kültür bakımından, ekonomik bakımdan güçlü, kudretli bir durumda olduğun zaman devlet de kendiliğinden ebet-müddet olacaktır zaten. Fakat ekonomi zayıf, dilin zayıf, kültürün zayıf, millet birliğin zayıf olup yıkıldıktan sonra istediğin kadar bağır Filistinliler gibi. Benim devletten anladığım budur.

Devletin önceliğine ve güçlü olması gerektiğine inanan DP'li bir siyasetçiye göre "milletsiz devlet olmaz, devlet de milletsiz olamaz"; bunlar birbirini tamamlayan ve bütünleyen unsurlardır fakat devlet her zaman güçlü olmalı ve bunu herkese hissettirmelidir:

Devlet dediğiniz soyut bir kavram zaten. Elbette devlet milletten ayrı bir kavram değil. Bunu ayrıştırmak asıl problemi yaratıyor diye düşünüyorum. Devlet kavramını bir tarafa koy, elbette onun yıpranmasına izin vermeyiz. Çünkü onun yıpranması direkt olarak milletin yıpranmasını gerektirecektir diye düşünüyorum [...] Türkün, biliyorsunuz üç bin yıl yazılı iki bini yazısız beş binlik yıllık tarihi var. Ve beş bin yıldır da devlet geleneği olan bir milletiz. Dolayısıyla Türklerin genlerinden gelen devlete bir kutsiyet addetme anlayışı zaten var. Bunu bir günde, iki günde silme şansınız zaten yok.

SP'li bir siyasetçiye göre üzerinde yaşanılan toprakları edinmek için, "millet ve devlet bir arada, eğrisiyle 
doğrusuyla büyük bir çaba sarf edilmiştir”. Bu millet, "hem kendi hem de devletinin bekası için canını, malını gözünü kırpmadan feda edebilmiştir ve bundan sonra da aynısını yapabilecek"tir.

Devlet ile milletin birbirini aynı anda var ettiği sıklıkla vurgulanmasına karşın 'bekâ' meselesi gündeme geldiğinde genellikle devlete, millet ve bireye nazaran öncelik atfedilmektedir. Bu anlayışta devletin varlığı, ulus ve birey karşısında zaman zaman oldukça abartılı sayılabilecek gerekçe ve anlatımlarla göz ardı edilmektedir. 'Ebed-müddet-devlet'in değişmez bir ilke olduğunu söyleyen MHP'li bir siyasetçiye göre "devleti sorgulamaya başladığınızda devletin bekası zarara uğrar ve bundan kaçınılmalıdır”. Bu söylemin en dolaysız ve açık ifadesini BBP'li bir siyasetçinin anlatısında görmek mümkün:

Benim için devletim her şeyden öncedir; hani 'bir âlim öleceğine bin âlem ölsün’ diye bir atasözümüz vardır ya. Âlimden kasıt devlettir. Şimdi devlet kavramı benim için kutsaldır. Yani ta 6000 yıllık bir tarihten bahsediyorum. Hükümetler, Aliler, Veliler çok önemli değildir. Bizim standart bir ömrümüz var; gelir, yaşar gideriz. Benim hayallerim, hülyalarım, sevdalarım ebedi bir rüya. Devlet ve millet, kıyamete kadar, dünya var oldukça var olmalı diye düşünüyorum. Bunun için de gerektiğinde acımasız olmasının gerekliliğine de onay veriyorum. Yani yeter ki Türkiye yaşasın. Yeter ki Türkiye Cumhuriyeti’ni, Türkün dünya arenasındaki yerini, varlığını var eden devlet yaşasın, ben yok olmaya razıyım. Kendime paye biçmiyorum, kendimi de o noktada sadece meselenin bir hizmetkârı olarak görüyorum, uşağı olarak görüyorum. O kutlu sevdanın bir değneği olmak istiyorum. Yani devlet çok kutsaldır, dinim kadar kutsaldır. Hatta benim dinim yokken devletim vardı, o kadar kutsaldır. Benim devletçilik anlayışımda anama babama bile tavizim yoktur. Yani benim devletim öleceğine, babam ölsün derim ve bundan dolayı da Allah bana hesap sormaz diye düşünüyorum. Yani bir insanın babası için, anası için böyle düşünmesi ne kadar etiktir diye sorulabilir. Niye? Dinimde var bunun reçetesi. 'Eğer ananız babanız sizi bana şirk koşarsa' diyor, 'onları atmakta günah yoktur' diyor. Dinimiz böyle diyor, Allah böyle diyor, Allah’a şirk koşarsan. Yani hiçbir güç benim devlet anlayışımın üstünde değildir.

Başlangıçta da değinildiği üzere, zayıf bir eğilimi yansıtmasına karşın devletin kutsallığını ve onun bireylere önceliğini kabul etmeyen siyasetçilerden de söz edilmelidir. Örneğin MHP’li bir siyasetçiye göre devlet insanlara "hizmet etmekle" yükümlüdür: "devlet insan için var, kutsal devlet diye bir şey yok. Eğer insanlarını mutlu edemiyorsa, insanlarını bir yere yöneltemiyorsa, faydalı olamıyorsa orada bir sa- katlık var"dır. AKP'li bir siyasetçiye göreyse "devlete kutsallık atfetmenin mümkünatı yoktur, kutsal olan dini değerlerimizdir. Ceberut ve zalim olan bir devlet nasıl kutsallaştırılabilir ki??". Devletin kutsallı̆̆ını kabul etmekle birlikte devletin, millet için var olması gerektiğini dile getiren bir başka MHP'li siyasetçiye göre devlet "kutsal ve kurumsal bir çatıdır". Fakat bu çatı vatandaşlarına karşı adil ve şefkatli olmalı, kimseye hatta kendisini temsil eden kişi ve kurumlara bile imtiyazlı davranmamalıdır. "Devlet baba"dır diyen fakat ona "kutsiyet" atfetmediğini belirten DP'li bir siyasetçiye göre de, "hata yaptığında" devletin otoritesi sorgulanabilir.

\section{Sağ-Muhafazakâr Gelenekteki Kısmi Farklılık: Milli Görüş ve Devlet Telakkisi}

SP'li siyasetçilerin devlet konusunda diğer sağmuhafazakâr siyasetçilerden farklı görüş ve değerlendirmelere sahip olduğu belirtilmelidir. Bir entite olarak devlet, SP’li siyasetçiler için önemini korusa da bu önemin kaynağı bizatihi devletin a priori yalın varlığı veya 'ontolojik statüsü' değil Sünni-İslami teolojinin "ulul emre itaat" düsturunda anlam kazanıyor görünmektedir. Sözcük anlamı emir vermek olan kavram, yönetme yetkinliğine sahip olanlara itaat etme anlamına gelmektedir. Kavram Kuran-1 Kerim'in Nisa Suresi'nin 59. Ayet'inde yer almaktadır: "Ey İman edenler! Allah’a itaat edin. Peygambere ve sizden olan ulul emre (idarecilere) de itaat edin". "Ulul emr", İslami siyasal doktrinin farklı kanatlarını temsil eden Şiilik ve Sünnilikte farklı yorumlanmaktadır. Sünnilikte kavram çoğunlukla 'halife' veya yöneticiler biçiminde anlaşılırken; Şilikte ise kavramdan doğrudan siyasi otorite değil 'imamlar' anlaşılmaktadır (Lewis, 2007; Arkoun, 1999).

SP'li siyasetçilere göre devlet, bu ilkeyi temsil ettiği ve onun vazettiği ilkeye uyduğu ölçüde meşrudur. Bu ilkeye göre "en kötü otorite otoritesizlikten yeğdir". "Ulul emri" temsil ettiğine inanıldığı ölçüde devlete isyan ve başkaldırı söz konusu olamaz. Bu bağlamda SP'li siyasetçiler sıklıkla devlet ve hükümet arasındaki ayrıma dikkat çekmektedirler. Buna göre hükümet her zaman ve koşulda devleti temsil etmemektedir. Bu nedenle Kuran'a ve sünnete ters düşen uygulamalar yapan hükümetlere karşı çıkılabilir ve bu "meşru bir haktır". SP’li siyasetçilerin önemli bir kısmıysa devlete kutsallık atfetmemekte tam tersine bireyi "kutsal" saymaktadırlar.

SP’li siyasetçilerin çoğu, diğer sağ-muhafazakâr siyasetçilerin devlet, ulus ve bunlar arasındaki ilişkilerin 
mahiyeti konularında onlarla farklılaşan görüş ve değerlendirmelere sahipler. Bunun Milli Görüş geleneğinin sahip olduğu İslamcı ideolojiyle ilişkili olduğu söylenebilir. Kaynağını ve temel referanslarını Kuran ve sünnetten alan bu yaklaşımda devlet "ulul emr" ilkesi uyarınca önem taşıyan bir kurumu ifade etse de son kertede ona kutsallık atfedilmemektedir. Ümmet ve cemaate hizmetle yükümlü olan devlet bu bakımdan bir "aygıt"tan öte anlam taşımamaktadır. Milli Görüş geleneğinde bu anlayışın net ifadesinin "gardiyan değil garson devlet"te somutluk kazandığı söylenebilir. Kutsal olan devlet değil ümmeti veya cemaati oluşturan bireylerdir. Devlet, her unsura eşit hizmet sunmakla yükümlüdür. Devleti oluşturan farklı unsurlar söz konusu olabileceği için devletin bu unsurlara inanç ve ideoloji dayatması kabul edilemez bulunmaktadır. Teorik olarak bu yaklaşım devlete kutsallık atfetmeyi de mümkün kılmamaktadır. Devlet anlayışı böyle tarif edildiğinde devlet ile birey veya devlet ile ulus arasinda da kurulması lazım gelen herhangi bir organik tasavvur, öncelik-sonralık ilişkisi kurulmamakta; devlet sadece millete hizmet etmekle yükümlü bir organizasyon olmaktadır. Kutsiyet atfedilmeyen devletin otorite ve meşruiyeti Kuran ve sünnetten uzaklaşıldığı ölçüde de eleştirilebilir görülmektedir. Hatta bu türden bir devlete isyan "farz" kılınabilmektedir. Ancak bu noktada kutsiyetin niteliğine ilişkin bir ayrıma vurgu yapmak gerekli görünüyor. Yalın bir entite olarak devlete kutsiyet atfedilmemesi devletin yüceltilmediği anlamına gelmeyebilir. Devlete dair bu tutum ona yönelik eleştirel bir mesafeden çok, Osmanlidan mülhem bir kavram olan "din-û devlet"4 telakkisinin bir yansıması olarak da okunabilir. Devlet ile millet (veya ümmet) bir bütünlügü, tam bir örtüşmeyi işaret ettiği ölçüde "din- û devlet", kutsallık atfı yapılmaksızın da yüceltilen bir doktriner (İslami) ideal ya da ilke olabilir. SP’li siyasetçilerin devlete ilişkin genel yaklaşımını yansıtan anlatısında SP'li bir siyasetçi şunları dile getiriyor:

Şimdi devlet, hükümet ya da rejim arasındaki farkı ya da nüansı mutlaka görmemiz lazım. Devlet bir toprak parçasında bulunan ülkemizdir. Topraksız, vatansız devlet olmaz. Devlet denen şey toprakla, bir coğrafyayla mutlaka tezahür etmelidir. Dolayısıyla devletler kalıcıdır, hükümetler ve rejimler geçici olabilirler. Devlet daimidir, toprak parçası kaldığı müddetçe devlet de

4 Kavram hakkında ayrıntılı bilgi için bkz. (İnalcık, 1994). kalıcıdır. Sosyolojik olarak da bu böyle, ama hükümetler ayrı; bazıları hükümeti ve rejimi devlet olarak görüyorlar, bunu biz kabul etmiyoruz. Devlet ayrı şey, devletin yürütücüsü olan anlayış, fraksiyon, ideoloji, rejim hükmü ayrı şeydir. Dolayısıyla İslam literatürüne baktığımız zaman, İslam nokta-i nazarından baktığımız zaman, evet ulu'l emre itaat farzdır [...] Kuran'da emir var, itaat çok önemlidir. "Allah'a itaat edin, Resul'üne itaat edin ve sizden olan ulu'l emre itaat edin" deniliyor. Dolayısıyla ben itaat etmekle yükümlüyüm, ama kime? Benim inancımı çiğneyen, benim inancıma bunlar irticadır diyen, benim başörtülü kız kardeşimi üniversitelere almayan, benim çarşaflı bacımı kara çarşaf diye, çağdışı elbise diye nitelendiren, faiz dünya gerçeği diyen, kumarhaneler kurmakla devlete gelir elde ettiren bir anlayışa ben asla itaat edemem ve asla onlara ulu'l emir sıfatını veremem. Ama yasalar gereğince, ama mevzuat gereğince, yasaların bana vermiş olduğu çerçevede onlara uyarım, uymak zorundayım. Fakat aslında ulu'l emir kavramı İslam devletiyle, İslam coğrafyasıyla yakından ilgili ve ilişkili bir olgudur, anlayıştır. Dolayısıyla İslam devletinin olmadığı, İslam hukukunun cari olmadığı toplumlarda elbet ulu'l emir kavramı ya da halife kavramı kullanılmayacaktır.

"Asli" anlamıla devleti aynı amaç ve tarihsel birlikteliği olan insanların bir araya gelerek oluşturduğu "çatı bir kurum" olarak tarif eden SP’li bir başka siyasetçiye göre Türkiye'de devlet, "milletin önünde yer alan bürokratik elitin bir oyuncağıdır". Oysa devlet herhangi bir seçkin zümrenin baskısının aracı değil millete hizmet eden ve herkese eşit mesafede duran bir organizasyon olmalıyd. Devletin ideolojik misyon dayatmasını ve toplum karşısındaki gücünü eleştiren SP’li bir başka siyasetçi ise şu değerlendirmelerde bulunuyor:

Devletin tarifini iyi koyamadığımız müddetçe sıkıntı çekiyoruz. Devlet dediğimiz hadise, neticede bir kurum, ama onu oluşturan şeyler de biziz. Fakat devlet bir ideolojik işlevi de beraberinde getirdi, yani insanları dönüştürmek isteyen bir kurum haline geldi. O ideolojik yapı olduğu müddetçe sıkıntılar da artıyor. Şimdi öyle bir çözüm buldular ki, devletin ceberut olması anlayışı Batı da geçerlidir. Bunu kabul ettiler, buna karşılık devlete karşı insanları, toplumları koruyabilmenin yollarını aramaya başladılar. Hâlbuki devlet, asgari anlamda, olması gereken anlamında halkıyla iç içe, halk tarafından idare edilen bir sistem olması gerekirdi. Fakat bunu başaramayınca bu sefer sivil toplumu devreye sokmaya çalıştılar. İşte anayasalar devreye girdi, anayasa aslında bizdeki gibi devleti koruyan değil de güçsüz olanı koruyan, halkı koruyan bir şey olması lazımdı. Fakat sonunda devlet öyle güçlü bir hale geldi ki, anayasayla kendini koruyan, sivil toplum kuruluşlarını da denetleyen bir kurum haline geldi. 


\section{Sağ Muhafazakârlık ve Devlet Mitinin Kökenine Dair}

Buraya değin anlatılarda ortaya çıkan durumu dikkate alarak şu soruyu sormak gerekiyor; devlete dair söz konusu mitik algılamaların kaynağı nedir ve bu algı ve tahayyüller ne anlama gelmekte ve ne anlatmaktadır? Bu sorulara yanıt vermeden önce çok kısaca da olsa devlet mevhumuna yönelik siyaset kuramı veya felsefesinde devletin nasıl ele alındığına ilişkin bir not düşmekte fayda var. Siyaset felsefesinde devletin iki temel düzlemde ele alındığı söylenebilir. İlk yaklaşımda devlet, tarihsel ve olgusal bir gerçeklik olarak ele alınır. Buna göre devlet, 'doğal' bir oluşum değil; sosyo-ekonomik ve siyasal faktörlere göre tarihsel süreçte değişim gösteren örgütsel bir çerçevedir. Burada devlet, toplumların ihtiyaçlarına göre örgütlenme özellikleri, iktidar pratikleri ve meşruiyet esasları farklılık arz eden bir oluşumdur (Öztan, 2010, s.426). Örneğin Cassirer bu eğilimi temsil eden düșünürlerdendir. Ona göre insanlık tarihinde devlet, mevcut formunda uygarlaşma sürecinin geç kalan bir ürünüdür. İnsan, bu toplumsal düzen formunu keşfetmezden önce, duygularını, isteklerini ve düşüncelerini anlamağa girişti. Böyle düzenlemeler ve sistemleştirmeler, dilde, efsanede, dinde ve sanatta gerçekleştirildi. Eğer biz bir insan kuramı geliştirmek istiyorsak; siyasal yapıdan daha geniş olan bu temeli kabul etmeliyiz. Çünkü, ne kadar önemli olursa olsun devlet, her şey değildir" (Cassirer, 2005). İkinci felsefi yaklaşım ise devleti tarihsel değişiminden ve sosyolojik bağlamından bağımsızlaştırarak 'metafizik bir unsur' olarak değerlendirme eğilimindedir. Buna göre 'devlet ezelden bu yana hep vardır ve insan toplulukları mevcut olduğu sürece hep de var olacaktır. Devletin 'mitsel özellikler' ile donatılması, çoğu zaman onu kategorik bir yanılmazlık/sorgulanamazlık zırhı ile kuşatmıştır (Öztan, 2012, s.426). Bu eğilimi temsil eden en önemli filozof ise Hegel'dir. Ona göre devlet nesnel ahlak idesinin eylem halindeki gerçekliğidir, kendi kendini bilen ve düşünen ve bildiği için yapan tözsel iradedir. Devlet, örf ve adetlerde dolaysız olarak; bireyin kendilik bilincinde, bilgisinde ve etkinliğinde ise dolaylı olarak mevcuttur. Buna karşıllk, birey de devlette, kendi öz içeriğine, ereğine ve etkinliğinin bir ürününe bağlanarak, onda kendi tözsel özgürlügünü bulur (Hegel, 1991). Gerek siyasetçilerle yapılan mülakatların içerikleri gerekse de devleti ele alan ilgili felsefi literatüre bakıldığında burada sözü edilen devlete dair felsefi yaklaşımların izdüșümlerine rastlamak mümkün görünüyor. Öztan'ın da belirttiği üzere: “Türkiye özelinde ülkenin siyasal yapılanması ve kültürü mercek altına alındığında 'devletin kutsiyeti' inancının ve 'devlet baba' tamlamasıyla özetlenen paternalist zihniyetin hatırı sayılır bir ağırlığa sahip olduğu sıkça dile getirilen bir konudur" (Öztan, 2012, s.426).

Türkiye'de gerek ulus-devlet'in inşası süreci gözetildiğinde gerekse de sağ-muhafazakar/milliyetçi düşünce söz konusu olduğunda milliyetçiliğin ve ideolojisinin devlet mevhumunu ele alırken son derece önem taşıyan konu başlıklarından olduğu aşikardır. Milliyetçilik literatüründe olguyu siyasal bir dönüşüm olarak ele alan yaklaşımların en fazla üzerinde durduğu konu ulusların -modern anlamda- oluşumunda siyasal örgütlenmenin aldığ 1 yeni biçimleniştir (ulusdevlet). Bu bağlamda bağımsızlık, milli çıkarlar, hukuksal tabiiyet, vatandaşlık, uluslararası sistemdeki hukuksal gelişmeler, toplumsal mühendislik vb. gibi kavramlar üzerinde yoğunluğuna durulmuştur. Uluslaşma genellikle modernliğin siyasal ve hukuksal örgütlenmesinin bir ürünü ve yapılanma biçimi olarak nitelendirilir. Bu bağlamda, örneğin John Breuilly 'bir siyaset biçimi olarak milliyetçilik'ten, Paul Brass 'milliyetçiliğin seçkinlerce kullanımi'ndan, Eric Hobsbawm 'icat edilen gelenekler'den söz eder (Özkırıml, 1999). Öte yandan örneğin Ernest Gellner'e göreyse milliyetçilik 'siyasi ve milli birimin birbiriyle uyumlu olması gerektiğini savunan ilkedir' ve modern çağa özgü bir olgudur (Gellner, 2008). Bu alandaki bir diğer önemli sosyal bilimci Benedict Anderson, milletin ve milliyetçiliğin özel bir kültürel yapım (artefact) türü olduğu düşüncesindedir. Anderson’a göre bu yapımları anlayabilmek için tarih içinde ne zaman ve nasıl doğduklarını, zaman içinde anlamlarının nasıl değiştiğini ve neden bugün böylesine güçlü bir duygusal meşruiyete sahip olduklarını çözümlememiz gerekir (Anderson, 1991). Ulusun ve devletin inşasının neredeyse iç içe geçtiği ve çeşitli görünümleriyle milliyetçilik ideolojisinin Türkiye örneğinde devlet mitosunun tahkimi sürecinde ne denli önem taşıdı$\breve{g}_{1}$ ilgili literatürün sıklıkla vurguladığı bir konudur. $\mathrm{Bu}$ tartışmalara makale çerçevesinde ayrıntılarıyla değinmek mümkün olmasa da aşağıda, ulus devletin oluşumu sürecinde bizatihi devletin ideolojik ve pedagojik araçları kullanarak devlet mitosunu tahkim edilişine değinmeye çalşacağız. Kuramsal olarak kısaca değindiğimiz bu ara değerlendirmeleri akılda tutarak yukarıdaki sorumuzu yineleyebiliriz: devlete dair söz konusu mitik algılamaların kaynağı nedir ve bu alg1 ve tahayyüller ne anlama gelmekte ve ne anlatmaktadir? 
SP’li siyasetçilerin önemli bir kısmı dışarıda bırakılarak söylenirse, yukarıda yer verilen anlatıların ortaya koyduğu devlet ve otorite algisının pre-modern bir tarih kavrayışından türediği söylenebilir. Bu tarih kavrayışı ve algısında ideolojik-değer yönelimli bir tarih tasarımı ve yazımının güçlü bir etkiye sahip oluşu göze çarpıyor. Söz konusu algının yerleşiklik kazanmasında uluslaşma sürecinin pedagojik vasıtalarının (ders kitapları, haritalar vb.) son derece etkili olduğu ve içselleştirilerek günümüze aktarıldığ görülmektedir. Böylesi bir tarih ve bununla uyumlu devlet-otorite kavrayışının erken cumhuriyet döneminde ortaya konulan tarih tezleriyle, özellikle de "romantik" tarih tasarımının çok daha belirgin olduğu I. Türk Tarih Kongresi’nin (1932) tezleriyle (Türk Tarih Tezi) bağlantılı olduğu görülüyor. I. Kongre’de Türk tarihinin idealleştirilmesi ve etnisist bir söylem egemenken, İkinci Kongre'den (1937) 1950’lere kadar olan dönemde, ilk kongrede üzerinden atlanan Osmanlı tarihi daha fazla içeriliyor fakat yine de Devlet Mitos'unun tahkim edildiği görülüyor (Bora, 2006, ss.44-45). Genel hatlarıly Türk Tarih Tezi, Türk ırk1nın bütün medeniyetlerin kurulmasında belirleyici ve merkezi bir rol oynadığı iddiasına dayanıyordu. Buna göre, Mezopotamya, Mısır, Anadolu, Çin, Girit, Hindistan, Roma'da kurulan medeniyetlerin kökeninde Türklerin Orta Asyadan Doğu’ya, Batı'ya ve Güney’e göçleri bulunmaktadır (Copeaux, 1998, s.40). Tezin, süreç içinde birçok değişikliğe uğramasına ve revizyona ${ }^{5}$ tabi tutulmasına karşın esasta sahip olduğu etnisist vurgusunu muhafaza ettiği söylenebilir. Söz konusu tezde, Türklüğün çeşitli ('üstün') niteliklerine yönelik birçok unsur vurgulanmakla birlikte, devlet olgusuna yüklenilen anlamın özel bir öneme sahip olduğu anlaşılıyor. Buna göre Türklerin en önemli vasiflarından birisi 'devlet kurma' yeteneğidir. Devlete ilişkin türetilen bu mitolojide: “Türk Devleti, objektif ve normatif değerlerin üzerinde yer alan, kendi kendini meşrulaştırmaya muktedir bir üstün varlıktır; Türk devleti, herhangi bir devlet değil, bizatihi bir niteliktir" (Bora, 2006, s.63). Tezin müelliflerinden Şemsettin Günaltay’ın liseler için yazdığ 1 bir kitapta Türklerin devlet kurma yeteneğinin doğuştan varolan (fitri) bir özellik olduğu ileri sürülmektedir: “... Türkleri tarih sahnesine girdikleri zaman muntazam devletler kurmuş halde buluyoruz" (Günaltay, 1939, s.29'dan aktaran Behar, 1992, s.109). Tezin revizyonu süresince Türklerin tarih içinde kurmuş olduğu

5 Türk Tarih Tezi'nin zaman içinde uğradığı 'tashih' ve 'revizyon'ları, teze yönelik eleştiri, tutarsızlıklar ve bunların ayrıntılı bir analizi için bkz. (Behar, 1992). devletlerin sayısının on iki ile yirmi arasında değiştiği görülmektedir (Behar, 1992, ss.109-110). Taşkın’a (2007, s.32) göre: "Devletin kutsallaştırılması, hem rasyonel olarak hem de etik tarihsel yolculuğun en mütekâmil oluşumu olarak evrenselleştirilmesi, Türkiyédeki milliyetçi-muhafazakâr anlayışın en ayırt edici vasıflarındandır". Bora, "Milli Tarih ve Devlet Mitosu" başlıklı makalesinde "Türk Devleti” mitosunun unsurlarını on başlık altında inceler, bu unsurlar: 1. Devlet kuruculuk, 2. Türk devletleri arasında devamlılık, 3. Devletin kutsallığı, 4. Türk devletlerinin başından itibaren 'milli devlet' niteliği taşıması, 5. Merkezi/yetçi ve güçlü devlet geleneği, 6. Ordumillet, ordu-devlet, 7. "Devlet adamları"nın özel yeri, 8. Demokratik/halkçı ve "sosyal" devlet geleneği ${ }^{6}, 9$. Türk devletinin 'cihanşümulluğu' ve 10. Türk devletinin "pratikliği" ve "realistliği”" (Bora, 2006, ss.45-63; Bora ve Can, 2004, ss.125-157). Alan araştırmamızın bulgularıyla Bora’nın yaptığı bu sınıflandırmanın beş tema etrafında örtüştüğü görülmektedir. Borảnın da vurguladığı üzere, dikkat çekici olan bu yaklaşımların pre-modern niteliği, tarih dışıllığ 1 veya tutarsizlıkları (Bora, 2006, s.44) değil, tersine, tam da bu niteliklerine rağmen, en azından sağ-muhafazakâr siyasetçilerce, söz konusu yaklaşımların bu denli kabul görmesi, güncelliğini sürdürmesi ve bu yanıyla da içselleştirilmiş oluşudur. Bora, Mitos’un bu niteliğini doğrudan doğruya güncel devlet mitosunun inşasına dönük bir pratik olarak yorumluyor: "gerek devletin "sahibi" kabul edilen "çekirdek devlet" kurumlarının, başta TSK/MGK’nın ideolojisinde, gerekse ilk-orta öğretimde ve popüler tarih algısında, bütünlüklü bir şekilde vazedilmese de Türk Tarih Tezinin temel kaziyeleri geçerliliğini koruyor. Ayrıca, resmi tarihten ayrışan Türkçü-Turancı ve milliyetçi-muhafazakâr tarih mitolojileri de, hem tematik yönünden hem de temel karakteristik kalıplar yönünden aynı anlayışı sürdürmüşlerdir” (Bora, 2006, ss.44-45). Türk Tarih Tezinin ve önermelerinin ırkçılık vb. sınırlı bir tematik çerçeveye sıkıştırılmasına ve tezin apolojetik okumalarla geçiştirilmesine yönelik yaptığı uyarısında Yeğen, (1996, ss.19-24 ve 1999, ss.190-191) tezin, modern Türkiye siyasetindeki etkisinin göz ardı edilmemesi gerektiğini vurgular: "modern, milli ve merkezi bir idari-politik entitenin inşasının asli bir unsuru olan milli kimliğin tahayyül edilme faaliyetindeki oluşsal elemanlarından biri olmuş bulunan Türk Tarih Tezini, Türkiye siyasi tarihinde bir kaza anı olarak ni-

6 Kalkınma söylemi ile Türk sağ-muhafazakarlı̆̆ında devletin yüceltilmesi konularındaki bağ ve ilişkiye dair dikkat çeken önemli bir çalışma için bkz. (Turan, 2012). 
telemenin mümkünat1 yoktur" (Yeğen, 1996, s.23). Bir kez daha vurgulamak gerekirse, devlet ve otorite bağlamında, sözü edilen tez'in taşıdığı anlam ve önemin onun güncelle olan uyum ve ilişkisellikte olduğu söylenebilir.

Yukarıda yer verilen anlatılarda ortaya çıkan algı ve tarifler temel alındığında, devlete yüklenilen anlam ve işlev, ona atfedilen kutsallık, organik devlet-ulus tahayyülleri ve devlet ile ulus arasında tesis edilen ilişki mantığının aynı zamanda otoriter-faşizan eğilimleri yansıttığg da söylenebilir. Muhafazakâr ideolojinin otoriter tasavvurlarla ilişkisini vurgulayan İnce'ye (2010, s.19) göre:

"siyasal otoriteye karşı sorgusuz sualsiz bir bağllık içinde, disiplin ve itaat temelinde gelişecek olan davranışlarda ve tavırlardaki kararlılık, insanların kendi yaşamlarını denetleyen becerilerini geliştirecek bir bilinci doğrudan etkileyecektir. Böylesi bir yaşam anlayışı için gerekli olan hareket ettirici güç, gelecekte güçlü devlet olma, güçlü devlet ve ulus beklentisini taşıma ya da otoriter ve total devlete olan inancın desteklenmesi yoluyla, gerçekliğin mistik resimlenmesine gerek duyar".

Faşizmi homojen, tutarlı ve bütünlüklü bir ideoloji olarak (Breuer, 2010, s.7; Heywood, 2007; Eatwell ve O'Sullivan, 1993) ele almak her ne kadar mümkün görünmese de, onun devlet-otorite ve ulus tasavvurlarını asgari düzeyde benzeş kılan bir takım niteliklerinden söz edilebilir. Otoriteye verilen önem bu niteliklerden biridir. Faşistler otoriteyi sıra dışı yetenekli bir birey tarafından sahip olunan kişisel liderliğin veya karizmanın alameti olarak kabul ederler. Böylesi bir otorite, mutlak ve sorgulanamazdır veya öyle olmalıdır (Heywood, 2007, s.271). Anlatılarda ortaya çıktığı kadarıyla otoriteyi temsil eden en önemli figürün devlet olduğu görülmektedir. Yine anlatılarda belirdiği biçimiyle, devlet karşısında bireye, hatta devletin bekası söz konusu olduğunda, ulusa atfedilen rol de talidir; bireyin varlığ 1 ve iradesi devletin tasarruflarına bağlıdır. Bu durumun da faşist ideolojinin nitelikleriyle uyumlu olduğu söylenebilir. Mussolini ve Gentile için faşist devlet bilinçli bir oluşumdur ve kendine özgü bir iradesi vardır. Bu nedenle ahlaki bir bağlamda tanımlanabilir. Devletin varlığı yalnızca bireyin haklarının bastırılmasını vurgulamaz. $\mathrm{O}$, "insanların fiziksel görünüşlerini bile dönüştürebilecek”tir. Mussolini’nin mottosu sayılabilecek bir ifadeyle: "devletin içerisindeki her şey, devlete karşı hiçbir şey, devletin dışında hiçbir şey" (Mussolini, 1968, ss.39-40, aktaran Sternhell, 1994, s.250). Bir ideoloji olarak faşizmin milliyetçilik, ulus ve irk tahayyülünde herhangi bir türdeşlikten söz etmek mümkün görünmüyor. Heywood'un da belirttiği üzere faşizm türlerinin tamamı rrkçılık içermez ve her ırkçı da faşist değildir. Tarihsel-ampirik bir olgu-durum olarak, Türk sağ-muhafazakarlığının bir bileşeni olan milliyetçiliğin soy faşist bir ideolojik pozisyona yatkınlığından söz edilebilirse de (Özdoğan, 2001; Önen, 2005; Maksudyan, 2005) onu, burada ifade edilen anlamıla -ırkçı- faşist saymak aşırı bir iddia olacaktır ancak yine de paralellikler dikkat çekicidir. Parlảnın (1989) önerdiği biçimiyle Türk sağını (ve solunun çeşitli türevlerini) faşizme açık bir ideoloji olarak "korporatist-solidarist" nitelikleriyle değerlendirmek yerinde bir öneri sayılabilir. Örneğin, ulusu organik bir bütünlük olarak gören korporatizm ile faşizmin toplum kavrayışı arasında radikal bir farklılıktan söz etmek zor görünüyor. 'Tanımı gereği sağ bir ideoloji ve dünya görüşü’ olan korporatizm, toplumu, birbirine karşılıklı bağımlı ve kendi içinde uyumlu bir bütün olarak görür (Parla, 1989, ss.7-54). Ancak içerdiği faşizan ve otoriter eğilimlere karşın Türk sağ-muhafazakâr siyasetçilerini ve geleneğini tümüyle bu niteliği ile değerlendirmek mümkün görünmemektedir. Faşizm, devleti ve otoriteyi kutsamasına, yüceltmesine karşın salt bu niteliğine indirgenemeyecek de bir ideolojidir. Vurgulamak istediğimiz aralarındaki koşutluklar ve benzerliklerdir.

Otoritenin ve onu temsil eden devletin mitolojik alımlanışı, daha önce de değinildiği üzere, salt arkaik-tarihsel veya kazai-arızi bir anlatı olmakla sınırlı kalmayıp güncele de sirayet etmekte ve bu alg1 yeniden ve yeniden-üretilme ${ }^{7}$ potansiyeli taşımaktadır. Ancak bu yeniden-üretimin de kendiliğinden değil uluslaşma sürecinden kaynaklandığı ve bu süreçte ulus-devletin uyguladığ 1 belirli "ulusal-pedagojik" (Açıkel, 2002) stratejiler sonucu mümkün olabildiği söylenebilir. Açıkel’e göre:

"ulusçuluk, bireylerin anlam-dünyalarını şekillendiren başat özdeşleşme ve içselleştirme referanslarını yeniden yaratan başat ideolojik önkabul haline gelmekle kalmaz, aynı zamanda siyasal toplumsallaşmanın da temel yörüngesi haline gelir. Ulus-devlet, bir yandan teritoryal egemenliği, diğer yandan da siyasal-bürokratik araçlar yardımıyla toplum üzerindeki egemenliğini perçinler. Kitlelerin psiko-sosyal donanımlarını ulusal idealleri

7 Söz konusu yeniden-üretimin tesadüfî olmadığını ve kuşaklara aktarımını bir süreklilik olarak Türk-İslam Sentezi ideolojisi üzerinden okul kitapları bağlamında analiz eden önemli bir çalışma için bkz. (Copeaux, 1998). 
gerçekleştirecek şekilde biçimlendirir; yeni meşruiyetözdeşleşme alanı içinde bütün kaynaklarını sevk ve idare eder. Bu gelişme, yeni bir devlet-eksenli toplumsallaşma sürecinin doğuşuna işaret eder" (Açıkel, 2002, s.118).

Yine aynı yerde Açıkel'in belirttiği üzere Türkiye'de Ziya Gökalp'le başlayan ve otuzların Kemalist devrimleriyle somutlaşarak devam eden, ellilerden itibaren sağ-popülist renklere bürünerek dönüşen ve yetmişlerden itibaren yarı-resmi korporatist faşist renkler kazanmaya başlayan ulusçuluk deneyimleri, devletin resmi ideolojisine şekil vermenin yanı sıra, yeni toplumsallaşma biçimlerinin ortaya çıkışına da işaret eder (Açıkel, 2002, s.118). Devlet imgesinin kökensel kaynağ dayalı olsa da: "ulusçu imgelemin başarısı büyük ölçüde modern öncesi ve moderni, grup psikolojisi ve aklı, ve cemaat ve toplum arasındaki geçişliliği sağlamasına borçludur [...] ulus devlet, kendi mitolojisini yaratarak ve toplumu zihinsel-psikolojik olarak devletin bürokratik hakikat söylemine bağlı kılarak; bir tür ulusçu kolektivist ütopya ile dayanışma ve alturizm eğilimlerini besleyerek var olabilir" (Açıkel, 2002, s.121).

Genel bir eğilim olarak tarihin ve burada dile getirilen tarih anlayışıyla uyumlu olarak beliren devletinotoritenin mitolojik bir biçimde tasavvur edilmesinin ne anlamı bulunmaktadır? Yukarıdaki anlatılara atıfla altı çizilecek noktalara bakılacak olursa; böylesi bir pre-modern veya "icad edilen" tarih anlayışının ve bununla ilintili devlet-otorite tasavvurunun sağmuhafazakâr siyasetçiler nezdinde karşılık bulmasının, modern siyasetin siyasetçilerin önüne koyduğu güncel meselelerin tartışılması ve çözüm olasılıkları önünde ciddiye alınması gereken (ideolojik) bir engel oluşturduğu söylenebilir. Bu, salt sağ-muhafazakâr siyasetçileri değil aynı zamanda söz konusu geleneğe destek sunan kitlelerin tutumları için de göz önünde bulundurulması gereken bir durum sayılabilir. 'Tarihin siyasetin hizmetine' (Taşkın, 2007, ss.60-61 ve ss.135-174) bu denli ideolojik bir yükle koşulması basitçe teorik bir yanılsamanın veya sapmanın ötesinde pratik siyasal karşılıkları olabilen bir alan sayılmalıdır.

Araştırmanın sınırları içinde kalarak belirtmek gerekirse, sağ-muhafazakâr siyaset geleneğinin önemli bir hattını (AKP-MHP-DP) kesen bu mitik tarih-devlet-otorite anlayışının yerleşiklik kazanmasında hem resmi tarih anlayıșının hem de, belki de ondan daha fazla, resmi tarih anlayışıyla salınımlı-gerilimli veya ona zaman zaman eklemlenebilen Türk-İslam sentezi ideolojisinin payını vurgulamak elzem görünüyor. Sentez'in güncel siyasi bir tasarım-proje olarak hegemonik tutunumundan söz etmek mümkün olmasa da geriye bıraktığı ideolojik-zihinsel mirasın belirli bir süreklilik içinde evrilerek günümüze aktarıldığı söylenebilir. Üstelik bu miras yukarıda anılan hattın bir unsuruna değil tümüne birden çeşitli derece ve boyutlarıla sirayet etmiş görünmektedir. Copeaux (1998, ss.307-308) tarafindan "sağ, muhafazakâr ve milliyetçi bir akım” olarak tanımlanan Sentezi, belirli bir siyasi partiyle açıkça birleştirmek de mümkün değildir. Ancak, SP'nin, en azından siyasetçilerinin söyleminde, bu hattın içinde doğrudan yer almaması onun tarihi-devleti modern-rasyonel bir tarzda okuyor olmasından ziyade sahip olduğu islamcı ideolojinin bütüncül (holistic) ve kapsayıcı doğasıyla bağlantılı görmek gerekiyor. Nihai olarak, İslami telos ile milliyetçiliğin, sentez söylemi hilafına uyuşmayacağ1 açıktır. Fakat buna karşın, Milli Görüş geleneğinin de tarihe-devlete-otoriteye bakarken, sözü edilen hatla benzer bir zihinsel tutumdan uzak olmadığ 1 söylenebilir; farklılık söylemi-ideolojiyi kuran öğelere yap1lan vurguda belirginleşmektedir.

Otoriter-faşizan bir zihniyetin içselleştirilebilmesini göstermesi bakımından da yukarıda sözü edilen devlet algısının önem taşıdığı söylenebilir. "Baba"da cisimleșen otorite figürü ve ona olan bağlılık hem toplumsal-siyasal hem de bireysel olarak otoriteyle olan ilişkinin anlaşılması bakımdan önemli bir unsur olarak görünüyor. Bunu bir semptom olarak adlandırmak mümkünse eğer, bu semptomun politik-psikanalitik tezahürleri de söz konusudur. Bu tezahürleri "ulusal pedagoji” kavramsallaştırması ile okuyan Aç1kel'e göre (2002, ss.133-136):

“ulusal özdeşleşme aynı zamanda bir kişilik sorunu olarak kurgulanır. Ulusal pedagoji, ilkel toplulukların totemleriyle ve kabile sembolleriyle özdeşleşmesine benzer biçimde, kitleleri devletleriyle, törenleriyle, tarihleriyle ve liderleriyle özdeşleştirir. [...] Ulusun ailenin bir tür ikamesi olarak ortaya çıkmaya başladığı noktada; devlet de zımni olarak yurttaşlarını adlandırma-çağırma imtiyazına sahip olan bir paternal figür olarak ortaya çıkacaktır. [...] Çok uzaklardan getirilen bir mitolojik mirasın bugünün koşullarında yeniden üretebilmenin koşulu ulusal törenlerin kolektif hafızayı yönlendirmesidir [...] Uluslaşmak, bürokratik aygıtların gözetiminde pedagojik-ideolojik süreçlerden geçerek, otoriter bir ego-ideali karşısında kaotik bir bireysellikten siyrılmak ve ulus-devletin beklentilerine uygun biçimde toplumsallaşmak demektir”. 
Uluslaşma sürecinde bürokratik-merkezi devlet aygitının pedagojik-ideolojik müdahalelerinin (Tarih tezleri, ders kitapları, mitik sembollerin üretimi ve bunlara tapınç, törensellikler vs. aracılığıyla) otoriter-faşizan eğilimlere yataklık etmesini, Açıkel'in belirttiği toplumsallaşma sürecinden bağımsız değerlendirmemek gerekiyor. Nitekim söz konusu eğilimlerin hem siyasal tarihte hem de gündelik hayatta siyasal gönderim ve sembolleri de kapsayarak siyasal kıyım ve linç girişimleri ${ }^{8}$ biçiminde tezahür edebildiği de vakıadır. Ataerkilliğin, erkeklik söyleminin, militarizmin ve sair zihniyetlerin yeniden-üretimi ve anlaşılması bakımından devletin ve otoritenin bu denli yüceltilişinin ciddiye alınması gereken siyasaltoplumsal ve sosyal bilimsel ${ }^{9},{ }^{10},{ }^{11}$ bir soruna işaret ettiği söylenmelidir. Fakat bunu salt sağ-muhafazakâr gelenek değil sol addedilen kişi-yapı ve kurumlar için de soruşturulması ilgi çekici olacaktır.

\section{Cumhuriyet Rejimi ve Temsil Ettiği Devlet Algısı}

Yukarıda da tartışıldığı üzere salt bir entite-varlık alanı olarak devlet ve onun temsil ettiği otorite, sağmuhafazakâr siyasetçilerce büyük ölçüde olumlanır ve yüceltilirken cumhuriyetin kuruluşu ile somutluk kazanan devlet ve onun temsil ettiği otorite, değer ve ilkeler ise kayda değer ölçüde eleştiriye tabi tu-

8 Linç mantığı ve 'pratiğinin "Milli Refleks" söylemi üzerinden kitleleri nasıl seferber ettiğini ele alan iki çalışma için bkz. (Bora, 2008a; 2008b).

9 Bunu salt otoriteryan-faşizan eğilimlerin kökenini belirlemek veya anlamak için değil Türkiye’nin siyasal-toplumsal kültürüne ilişkin yapısal bir durumun tezahürü olarak da ele almak gerekli görünüyor. Bu alandaki boşluğa-eksikliğe dikkat çeken bir değerlendirme için bkz. (Açıkel, 2002).

10 Otoriteryanizmi ve otoriter sürekliliği salt 'devlet'e ve onunla ilişkili bir duruma indirgemenin zaafına değinen Ahmet Çiğdem yerinde bir uyarıda bulunuyor: "[...] bütün eleştirel enerjiyi devlete yoğunlaştırmak tersinden başka tür bir étatism'e zihinsel yatkınlık doğurmaktadır. Buna karşılık, toplumun kendisinde otorite uğraklarına direnebilmeyi mümkün kılacak bir insanlık ideali barındırdığına ilişkin herhangi bir emarenin, bir emare olarak bile anlamı yoktur. Toplumsal bütünün bütün uğraklarına, özellikle kişilik yapılarına, aileye ve kültürel değerlere sinmiş bulunan otoriteryanizm izleklerini daha mikro düzeyde çözümleyecek çalışmalar [...] otorite pratiklerinin nasıl süreklilik kazandığını gösterecek, böylece otoriter sürekliliğin aynı zamanda ve mutlaka toplumun omurgası üzerinden yürüdüğünü anlamamıza katkıda bulunacaktır" (Çiğdem, 2001, s.23).

11 Konuyu Türk muhafazakârlığı bağlamında "paternalizm" kavramı üzerinden analiz eden önemli bir çalışma için bkz. (Öğün, 2003). tulmaktadır. Bu bize göre dikkat çekici bir paradoks veya gerilime işaret etmektedir. Ayrıntılarına aşağıda değinileceği üzere devlete yönelik eleştirel mesafe bizatihi onun ontolojik-normatif varlığına yönelmekten ziyade cumhuriyetin modernleșmeci ideolojisinin ve onun devlet merkezliliğinin (kültüralist) eleştirisiyle sinırlı olduğu söylenebilir. Bu anlamda eleştirilen ve karşı çıkılan devlet, bir dizi ad ve sıfatlarla birlikte anılmakta veya nitelenmektedir. Aşağıdaki tabloda mülakatlardan derlenen devlet, cumhuriyet ve rejimine yönelik ad, sıfat ve çağrışımlara yer verilmektedir.

Tablonun ortaya koyduğu devlet-otorite temsili ile başlangıçtaki ortaya çıkan devlet temsili arasındaki radikal mesafe gerçekten dramatik bir farklılığa işaret etmektedir. Tabloda yer alan nitelemelerinin, herhangi bir bağlamdan kopuk yalın halinin bile cumhuriyeti temsil ettiği düşünülen devlete yönelik, sağ-muhafazakâr çevreler için kayda değer bir algısal çerçeve sunduğu söylenebilir. Cumhuriyet süreci ve onun modernleşme pratikleri söz konusu olduğunda devlete yöneltilen eleştirilerde "devletin kutsiyeti”nden söz edilmemekte, "baba" vasfına göndermede bulunulmamakta veya deyim yerindeyse bir "öz baba"dan beklenmeyecek tavır ve tutumlar takındığı ölçüde babaya karşı çıkılmaktadır. Yine deyim yerindeyse devlet nezdinde muhafazakâr kitlelerin (veya milletin-halkın-vatandaşın) "üvey evlat ${ }^{12}$ " konumuna getirilmesinden şikâyet edilmektedir. Daha önce görüldügü üzere, mutlak bir entite olarak 'devlet' yüceltilirken cumhuriyetle özdeşleştirilen devletin kıyasıya eleştirilmesinin çeşitli neden ve gerekçeleri olmalıdır. Bunun ilk dolaysız nedeninin, sağ-muhafazakârlığın devlet ve iktidar tahayyülüyle bağlantılı olduğu anlaşılıyor. Devletin mitik nitelikli algılanışı ile yeni rejimde tecessüm eden devlet algısı arasındaki farkın iktidara/güce olan mesafe ile ilişkili olduğu söylenebilir. Sağ-muhafazakârlık devlet iktidarına yaklaşabildiği ve onu massedebildiği sürece ona yönelen eleştirinin ve mesafenin dilinin de yumuşamakta ve giderek olumlanmakta olduğu anlaşılmaktadır. Cumhuriyet boyunca sağ-muhafazakâr geleneğin muhalif olduğu rejime yönelik radikal bir tavır veya eylemlilik geliştirememiş olması göz önün-

12 "Üvey evlat" bizim önerdiğimiz bir metafordur. Sağmuhafazakâr geleneğin bizatihi kendi ürettiği metafor veya imgelem ile kıyaslandığında, önerimizin son derece naiv kaldığı söylenmelidir. Bu bağlamda, Necip Fazıl Kısakürek'in "Sakarya Türküsü" isimli şiiri istisnai bir sembolik önem ve değere sahiptir. Bu şiirde ifadesini bulan söz konusu imgelemin, "mazlumluk söylemi" üzerinden fenomenolojik-psikanalitik bir analizi için bkz. (Açıkel, 1996). 
Tablo 1. Cumhuriyet Sürecinde Devlete Yönelik Ad, Sıfat ve Çağrışımlar

\begin{tabular}{||l||l||l|}
\hline \hline $\mathbf{1 .}$ & $\mathbf{2 .}$ & $\mathbf{3 .}$ \\
\hline \hline Korku & Statüko & Jakoben \\
\hline \hline Tabu & Istiklal Mahkemeleri & Darbe \\
\hline \hline Bask1 & Tek Adam & Ittihat ve Terakki \\
\hline \hline Yasak & Milli Şef & J̈n Türk zihniyeti \\
\hline \hline Ceberut & Tek Parti & Tepeden inmeci \\
\hline \hline Zulmeden & Jandarma & Dayatmaci \\
\hline \hline Horlayici & Polis & Toplumsal mühendislik \\
\hline \hline Prangaya vuran & Vali & Topluma Rağmen \\
\hline \hline Istibdat & Kaymakam & Sivil oligarşik bir sistem \\
\hline \hline Tahakküm & Muhtar & Rest çeken \\
\hline \hline Itaat & Vergi Memuru & Elit \\
\hline \hline Cunta & Bürokrasi & Soğuk \\
\hline \hline Engelleyici & & Uzak \\
\hline \hline Bask1 araci & & Yabanci \\
\hline \hline Otoriter & & \\
\hline \hline Tedbir & & \\
\hline
\end{tabular}

de bulundurulduğunda bu tespit de bir bakıma geçerlilik kazanmaktadır. Taşkın’ın milliyetçi-muhafazakâr entelejensiya üzerine olan çalışmasında da vurguladığı üzere milliyetçi-muhafazakârlık, muhalifken bile devlette konumlanmıştır, "milli kültürün yeniden ihyası ana projesinde" millet bileşenlerine değil devlete yaslanma tercihinde bulunmuştur (Taşkın, 2007, ss.58-61). Bu tercih, milliyetçi-muhafazakârlığın: "devleti ele geçirme ve siyaseti devlet kurumları etrafında cereyan eden bir seçkinler arası mücadele olarak algılamasının da nedenidir” (Taşkın, 2007, s.61).

\section{Sonuç}

Sağ ve muhafazakâr kimliğe sahip siyasetçilerle yapılan mülakatların ortaya koyduğu üzere, söz konusu siyasetçiler arasında devletin algılanması ve alımlanışındaki en temel öge devlet temsiline ilişkin mitik bir söyleme sahip oluşlarıdır. Bu algılayışta devlet yüceltilerek her türlü eleștiri ve mesafeden azade k1lınmaktadır. Devlete yönelik bu kavrayışın modern bir siyaset tasavvurundan uzak olduğu ise aşikâr görünmektedir. Ancak sorun tek başına devletin ve otoritenin modern niteliklerden yoksun oluşu ile ilgili bir algilayış değildir. Sorun mitolojilerden beslenen böyle bir algının günümüz modern hayatında siyasetçilerin zihninde yaygın bir geçerliliğe sahip olmasından kaynaklanmaktadır. Modern toplumun ve ondan bağdaşı olmayan modern yaşamın karmaşıklığı ve çeşitliliği göz önünde bulundurulduğunda, bu çeşitlilik ve karmaşıklığı kavrayarak hareket edebilen bir devlet ve siyaset tasarımına sahip olmak gerekmektedir. Modern toplumun sorunlarının çözümünün sözü edilen algı etrafında çözümlenebilmesi veya aşılabilmesi ise mümkün görünmemektedir. Dolay1sıyla, siyasetin taşıyıcısı ve üreticisi olan siyasetçilerin söz konusu algı ve perspektiflerini eleştirel bir değerlendirmeye tabi tutarak daha gerçekçi ve rasyonel tasarımlar üretebilmeleri gerekli görünmektedir.

\section{Kaynakça}

Açıkel, F. (1996). Kutsal Mazlumluğun Psikopatolojisi. Toplum ve Bilim, 70, 153-196.

Açıkel, F. (2002). Devletin Manevi Şahsiyeti ve Ulusun Pedagojisi. Tanıl Bora (Ed.), Modern Türkiye'de Siyasi Düşünce Milliyetçilik içinde (s.117-139). İstanbul: İletişim.

Anderson, B. (1991). Imagined Communities: Reflections the Origin and Spread of Nationalism, London: Verso.

Arkoun, M. (1999). İslam Üzerine Düşünceler, İstanbul: Metis.

Behar, E., B. (1992). İktidar ve Tarih Türkiye'de "Resmi Tarih” Tezinin Oluşumu (1929-1937), İstanbul: Afa.

Bora, T. (2006). Medeniyet Kaybı Milliyetçilik ve Faşizm Üzerine Yazılar, İstanbul: Birikim. 
Bora, T. (2008a). Türkiye’nin "Kriz İdaresi" Yöntemi: Milli Refleks ve Linç Orjisi, Birikim Dergisi, 116, 9-14.

Bora, T. (2008b). Türkiye’nin Linç Rejimi, İstanbul: Birikim.

Bora, T., Can, K., (2004). Devlet ve Kuzgun 1990’lardan 2000’lere MHP, İstanbul: İletişim.

Breuer, S. (2010). Milliyetçilikler ve Faşizm Fransa, İtalya ve Almanya Örnekleri, İstanbul: İletişim.

Cassirer, E. (2005). Devlet Efsanesi, İstanbul: Say.

Copeaux, E. (1998). Tarih Ders Kitaplarmda (19311993) Türk Tarih Tezinden Türk-İslam Sentezine, İstanbul: Tarih Vakfı Yurt.

Çiğdem, A. (2001). Taşra Epiği “Türk” İdeolojileri ve İslamcilk, İstanbul: Birikim.

Eatwell, R., O'Sullivan, N. (1989). The Nature of the Right American and European Politics and Political Thought since 1789, London: Twayne Publishers.

Gellner, E. (2008). Uluslar ve Ulusçuluk, İstanbul: Hil.

Hegel, G. F. W. (1991). Hukuk Felsefesinin Prensipleri, İstanbul: Sosyal

Heywood, A. (2007). Siyasi İdeolojiler, Ankara: Adres.

İnalcık, H. (1994). Şeriat ve Kanun, Din ve Devlet. İslâmiyat, I/4, 135-142.

İnce, H.,O. (2010). Muhafazakâr İdeoloji Din-Siyaset, İstanbul: Alan.

Lewis, B. (2007). İslamin Siyasal Söylemi, Ankara: Phoneix.

Maksudyan, N. (2005). Türklüğü Ölçmek Bilimkurgusal Antropoloji ve Türk Milliyetçiliğinin Irkçı Çehresi 1925-1939, İstanbul: Metis.

Öğün, S., S. (2003). Türk Muhafazakârlı̆̆ının Kültürel Politik Kökleri. Ahmet Çiğdem (Ed.), Modern Türkiye'de Siyasi Düşünce Muhafazakârlık içinde (ss.539-582). İstanbul: İletişim.
Önen, N. (2005). İki Turan Macaristan ve Türkiyede Turancilık, İstanbul: İletişim.

Özdoğan, G., G. (2001). "Turan"dan "Bozkurt"a Tek Parti Döneminde Türkçülük (1931-1946), İstanbul: İletişim.

Özkırıml, U. (1999). Milliyetçilik Kuramları: Eleştirel Bir Bakış, İstanbul: Sarmal

Öztan, G., G. (2012), Türk Sağında Devlet Fetişizmine Dair. İ.Ö. Kerestecioğlu ve G.G. Öztan (Ed.), Türk Sağı Mitler, Fetişler, Düşman İmgeleri içinde (ss.425-458). İstanbul: İletişim.

Parla, T. (1989). Ziya Gökalp, Kemalizm ve Türkiye'de Korporatizm, İstanbul: İletişim.

Sternhell, Z. (1994). Faşizm. David Miller (Ed.), Blackwell'in Siyasal Düşünce Ansiklopedisi, içinde (1. Baskı. Cilt 1, ss.247-251). Ankara: Ümit.

Suveren, Y. (2013). The Right Wing Conservative Politicians in Turkey: Ideological and Political Imaginations. (Yayımlanmamış Doktora Tezi). ODTÜ Soss yal Bilimler Enstitüsü, Ankara.

Taşkın, Y. (2007). Anti-Komünizmden Küreselleşme Karşıtliğına Milliyetçi Muhafazakâr Entelijansiya, İstanbul: İletişìm.

Turan,Ö. (2012), Kudretli Devlet, Manevi Kalkınma, Ağır Sanayii: Türk Sağı ve Kalkınma. İ.Ö. Kerestecioğlu ve G.G. Öztan (Ed.), Türk Sağı Mitler, Fetişler, Düşman İmgeleri içinde (ss.459-485). İstanbul: İletişim.

Yeğen, M. (1996). Türk Tarih Tezi ve Tarih Yazımı. Mürekkep Dergisi, 6, 19-24.

Yeğen, M. (1999). Devlet Söyleminde Kürt Sorunu, İstanbul: İletişim. 